\title{
Ceramics for high level radioactive waste solidification
}

\author{
Li WANG, Tongxiang LIANG ${ }^{1}$ \\ Institute of Nuclear \& New Energy Technology, Beijing Key Lab of Fine Ceramics, Tsinghua University, \\ Beijing 100084, China \\ State Key Lab of New Ceramic and Fine Processing, Tsinghua University, Beijing 100084, China
}

Received: August 21, 2012; Accepted: September 21, 2012

(C) The Author(s) 2012. This article is published with open access at Springerlink.com

\begin{abstract}
Several countries reprocess their nuclear spent fuel using the Purex process to recover $\mathrm{U}$ and $\mathrm{Pu}$ as MOX fuel. The high level radioactive waste (HLW) produced during this reprocessing is a complex mixture containing both radioactive (fission products, minor actinides) and non-radioactive elements. Since HLW shows high rate heat release and contains some long half-life and biologically toxic radionuclide, its treatment and disposal technology is complex, difficult and high cost. HLW treatment and disposal become a worldwide challenge and research focus. In order to minimize the potential long-term impact of HLW, studies on enhanced chemical separation processes of long-lived radionuclides are in progress. Two options are then envisaged for these separated radionuclides: (a) transmutation into short-lived or non-radioactive elements, (b) immobilization in highly durable ceramic matrix instead of borosilicate glass. In this paper, we briefly review the composition, structure, processing and product properties of some ceramic candidates for inert matrix fuels (IMF) and the immobilization of high level radioactive waste.
\end{abstract}

Key words: nuclear spent fuel; ceramic immobilization; transmutation; high level radioactive waste

\section{Introduction}

Every year about $10500 \mathrm{tHM}$ in spent fuel are discharged from the global nuclear power plants, up till now the total amount of spent fuel accumulated up to $280000 \mathrm{tHM}$. There are two strategies for spent fuel disposal: once through and reprocessing. For once through strategy, the spent fuel is closed and deep geological buried (better known as open fuel cycle), its drawbacks include high cost for large volume of storage, waste of nuclear resources, pose the main

* Corresponding Author.

E-mail: txliang@tsinghua.edu.cn radiotoxic risk after long storage time. If reprocessing is employed, the extracted $U$ can be returned to nuclear fuel production line as fresh fuel, or $\mathrm{U}$ and $\mathrm{Pu}$ are recycled as mixed oxide (MOX) fuel in light water reactor or fast reactor.

After reprocessing, the residual high-level radioactive nuclides such as long half-time minor actinides (MA) and fission products (FPs) constitute a threat to the environment. For the closed or advanced fuel cycle as shown in Fig. 1, the high level radioactive waste (HLW) will be immobilized within suitable inert matrices for its interim storage and disposal inside deep geological repositories. Research is also being pursued to segregate and separately irradiate long lived MA and FPs within critical and subcritical reactors to 


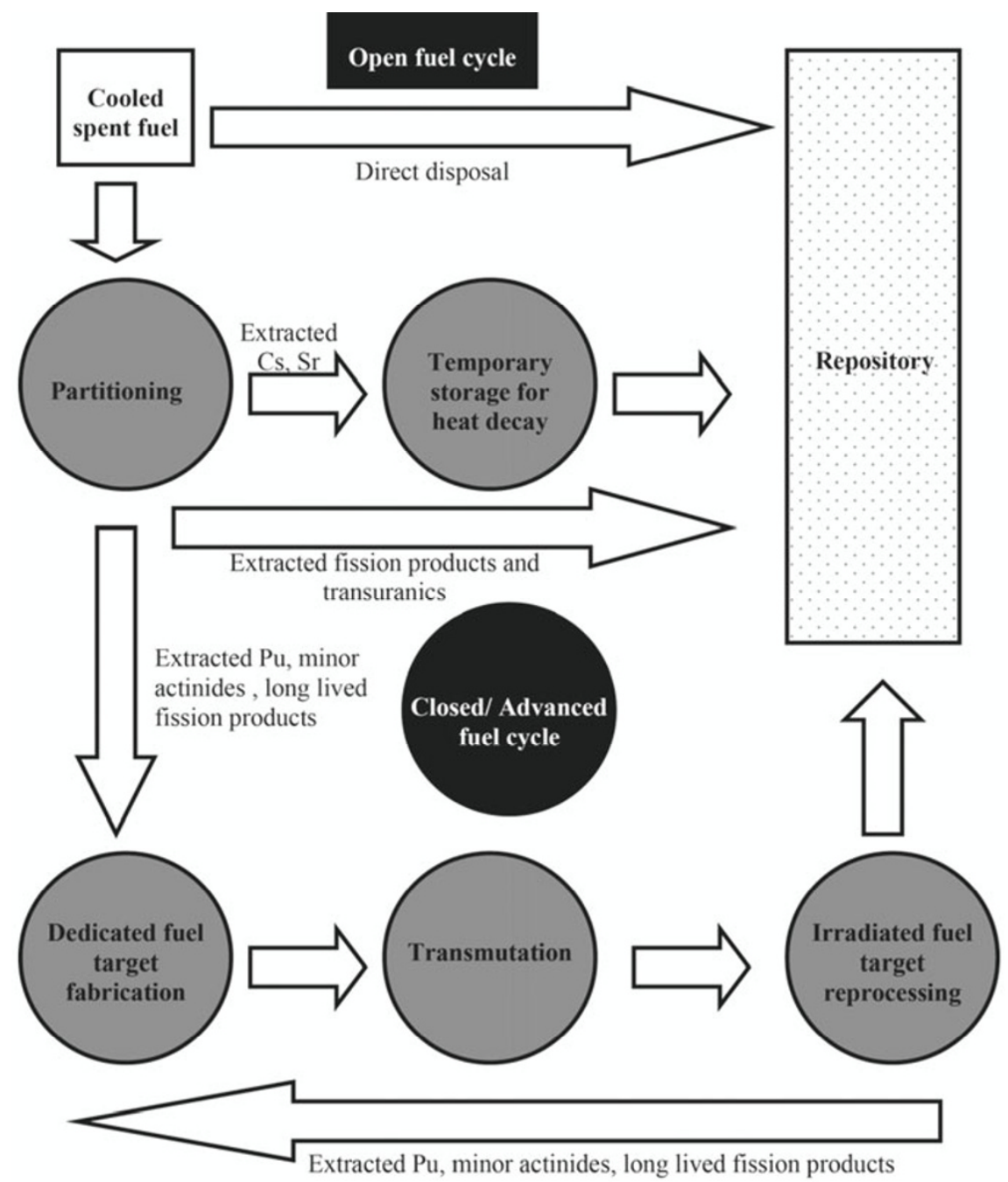

Fig. 1 Schematic diagram of open and closed nuclear fuel cycles [1].

convert them into shorter lived radionuclides.

Portland cement-based systems and glassed have long been identified as candidate matrices for solidification and isolation of Low- and intermediate level radioactive waste, how to deal with the high-level radioactive fission products and MA is a challenge and research focus $[2,3]$. In the past few decades, HLW arising from nuclear fuel reprocessing plants is immobilized in borosilicate glass. In high temperature, high pressure and watery environment, microstructure of glass will change, as a result, radionuclides is very easy to be leached out by water. Because of high melting point, high thermal conductivity, radiation stability, ceramics are regarded as the second generation of HLW forms. Many results showed that ceramic forms have superior chemical durability to glass forms [4,5]. Ceramic incorporation of waste elements is based on the isomorphism of mineralogy. Most actinides and fission products can be incorporated into polycrystalline phases, such as zirconolite, perovskite and hollandite. Some elements, such as $\mathrm{Mo}, \mathrm{Ru}, \mathrm{Rh}, \mathrm{Pd}, \mathrm{Ag}, \mathrm{Cr}, \mathrm{Fe}, \mathrm{Ni}$, etc. are reduced to metal during the fabrication and are incorporated into ceramic as alloy phases [6].

Another innovation option for MA (e.g., $237 \mathrm{~Np}$, 241 Am, 244Cm) and long lived FPs (e.g., 129I, 99Tc) disposal is transmutation by existing reactor or dedicated transmutation systems such as the accelerator driven systems (ADS). In this field, some research projects are started, such as ATW project in USA, OMEGA in Japan and EA project in European. In 1992, EFTTRA -T4 group was established, EFTTRA (Experimental Feasibility of Targets for Transmutation) is a network of research organizations in France (EdF and CEA), Germany (JRC-ITU and FZK) and the Netherlands (JRC-IAM and NRG), to study the transmutation of both americium and long-lived fission products technetium (99Tc) and 
iodine (129I) [7]. A pure lead cooled ADS reactor of 400 MWth dedicated to MA transmutation intended to be operational around 2040 in European under the EUROTRANS European project. At 2011, Chinese Academy of Sciences started a Strategic Priority Research Program named "Future Advanced Nuclear Fission Energy". ADS part will strive for self-development in the series key technologies from test facility to demonstrate facility.

In this paper, we briefly review some ceramic candidates for the transmutation and immobilization of HLW, in term of composition, structure, processing method and results.

\section{Inert matrix fuel (IMF) for transmutation}

Transmutation offers a means to reduce the radiotoxic inventory. In this case, MA should be first partitioned from the fission products in the reprocessed spent fuel and then incorporated in a fuel material. Different transmutation scenarios for MA are studied at present: mixing in fuels for existing reactors or in targets for ADS. In order to avoid the formation of new transuranium actinides due to the neutron capture by ${ }^{238} \mathrm{U}$, fertile is replaced by an inert matrix (IM) is advantageous [8]. Inert means that the compound is constituted of elements with low neutron capture cross sections.

The main requirements are good thermal and mechanical properties for the matrix and chemical stability in the course of its evolution for the actinide phase. Possible ceramic or metal candidate materials have been selected with criteria concerning their basic properties (thermal and mechanical properties, activation with neutrons, and chemical compatibility with neighboring materials) and their behavior under irradiation. Currently, several ceramics have been assessed as IM oxides (e.g., $\mathrm{ZrO}_{2}, \mathrm{MgO}, \mathrm{Al}_{2} \mathrm{O}_{3}$, $\mathrm{MgAl}_{2} \mathrm{O}_{4}, \quad \mathrm{Y}_{3} \mathrm{Al}_{5} \mathrm{O}_{12}, \quad \mathrm{CeO}_{2}$ and pyrochlore-type zirconate), nitride (e.g., $\mathrm{ZrN}$ ) or composites (ceramic-ceramic or ceramic-metal) [9-11]. The fissile atoms and the support matrix can either form a solid solution or be integrated in a composite fuel.

$\mathrm{ZrO}_{2}$ is the primary fuel matrix candidate internationally for IMF, however, it has low thermal conductivity and is difficult to reprocess using conventional processes, but its fairly good structure stability under irradiation, makes it a possible candidate that will be tested in near future. $\mathrm{ZrN}$ is considered one of the most promising inert matrices for nitride fuel cycles, since it has a low cross-section for neutron capture, high thermal conductivity and $\mathrm{ZrN}$ is thermodynamically stable up to high temperatures.

$\mathrm{MgO}$ provides good thermal conductivity, it is considered as a good candidate as IM [12]. Some irradiation tests showed that $\mathrm{MgO}-\mathrm{MA}$ pellets appearance was much closed to the fresh one, very small swelling rates were observed for the $\mathrm{MgO}$ fuel. $\mathrm{MgO}$ is not stable in water - a severe drawback for use in light water reactors. Some IMF activities have focused on a ceramic solid solution of $\mathrm{MgO}-\mathrm{ZrO} 2$. In this solution, the $\mathrm{MgO}$ provides good thermal conductivity and is easily dissolved in conventional acids while the $\mathrm{ZrO}_{2}$ provides resistance to water attack. After $700 \mathrm{~h}$ in $300^{\circ} \mathrm{C}$ deionized water at saturation pressure no cracking was found in $\mathrm{MgO}-\mathrm{ZrO} 2$. Although the pellets exhibited hydration reaction at the surface, the bulk of the $\mathrm{MgO}$ is protected by $\mathrm{ZrO} 2$ [13].

Behavior of $\mathrm{MgAl}_{2} \mathrm{O}_{4}$ spinel under irradiation is not fully understood up to now. Spinel behaves very well under high fast neutron fluencies, but fission products recoil or alpha decays product severe damage in the matrix. Irradiation test indicated that fast neutrons induce extensive dislocation-loop formation and big swelling in $\mathrm{Al}_{2} \mathrm{O}_{3}$ fuel, alumina lost its position for transmutation. Other matrices, such as $\mathrm{CeO}_{2}$, $\mathrm{Y}_{3} \mathrm{Al}_{5} \mathrm{O} 12, \quad \mathrm{Y}_{2} \mathrm{O}_{3}$ have been tested under neutron irradiation but the examination being still underway, their potential as matrices remains to appreciate.

Normally, IMF was prepared by infiltration of porous ceramic pellets with MA nitrate solution. The porous pellets were prepared by traditional ceramic process, such as press and pre-sintering. The pellets were lowered into MA nitrate solution, and maintained under the surface of the liquid for at least $10 \mathrm{~min}$. Upon withdrawal they were dried, and then calcined and sintered.

The infiltration technique can be automated, it is compatible with remote handling, and produces minimal quantities of dust and waste, as required for the production of MA fuel. However, further development is required to eliminate the possibility of inhomogeneities of the MA distribution in the pellets [14]. This inhomogeneity may be related to a non-uniform porosity of the uninfiltrated pellets or to a diffusion process during the thermal treatment.

IMF made by infiltration is called micro dispersed fuel, which shows high swell by the accumulation of 
helium (produced by alpha decay of $242 \mathrm{Cm}$ ) in gas bubbles under irradiation.

As indicated in Fig. 2, if the dispersed MA particle with a size between 50 and $300 \mu \mathrm{m}$, the damage will then be restricted almost completely in the MA particle. This fuel is called macro dispersed fuel. Figure 3 illustrated the swelling and damage of micro dispersed fuel, these unsatisfactory behaviors have not been observed in macro dispersed fuel [15].

When irradiated at high burn up, the contained gas is released from the host phase which could also lead to swelling of matrix. To reduce the damage of IMF, some solutions are put forward, for example by

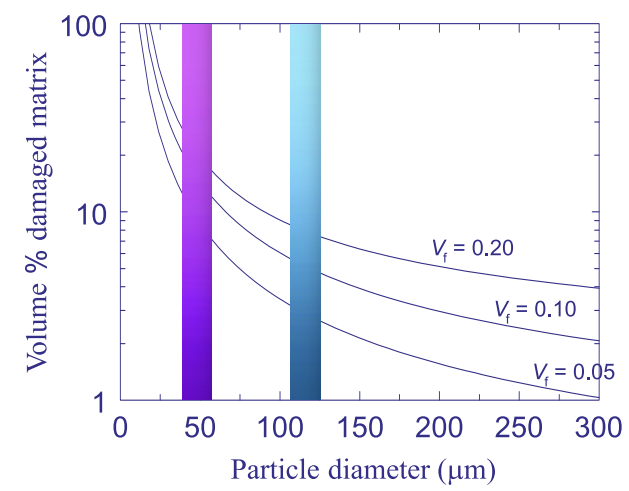

Fig. 2 Fuel particle size on the damaged volume of the matrix $[14]\left(V_{\mathrm{f}} \mathrm{MA}\right.$ content).

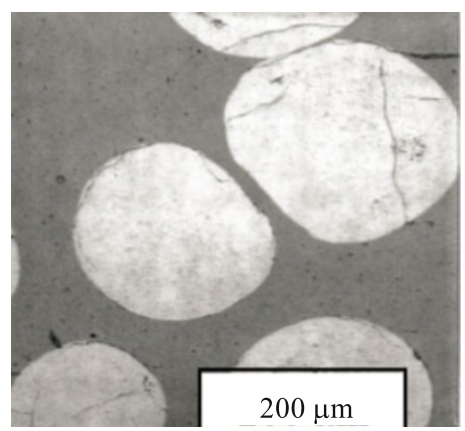

(a)

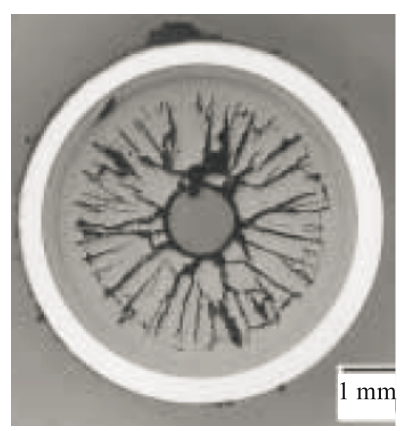

(b)

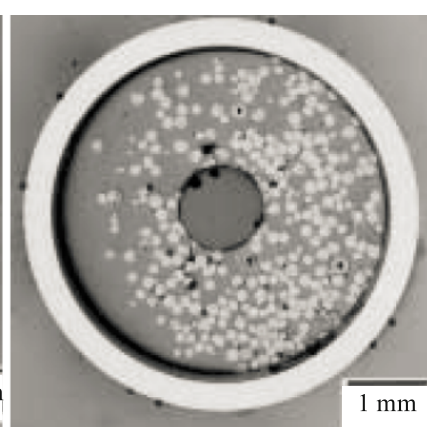

(c)
Fig. 3 Macro dispersed fuel (a), micro dispersed fuel (b) and macro dispersed fuel (c) after irradiation. MAOx white, ceramic matrix grey [15].
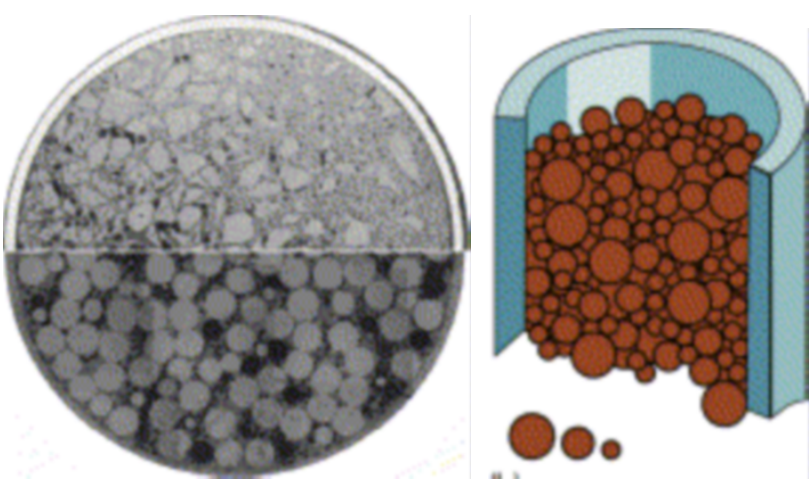

Fig. 4 The vipac (up) and sphere-pac (down and right) fuel concepts [16].

inclusion of tailored porosity to accommodate swelling or provide channels for release, by decreasing the smeared density of the fuel to permit pellet swelling, or, by using non-pellet type designs such as sphere-pac or vipac fuels (as shown in Fig. 4) [16]. In this fuel, gas can be stored in the gap or release out through the particle boundary, swelling can be reduced or eliminated.

One advantage of sphere-pac fuels is the dustless fabrication of "pellet-like" fuel. The handling of radioactive powders can be minimized and remote operations are simplified and minimized by fabricating micro-spheres with sol-gel or gelcasting methods just like $\mathrm{UO}_{2}$ kernels in high temperature gas-cooled reactor.

It should be note that in-pile test or simulate-irradiation test by accelerated beam must be investigated to assess the stability against the radiations produced in reactor. Under irradiation in reactor, three main sources of damage have to be considered for the IMF [11]: fast neutrons interaction, effects of fission fragments and alpha decay products (alpha particle + heavy recoil atom). These energetic particles produce damage through electronic and atomic interactions and the consequences that depend on the material, may affect significantly bulk properties: changes of lattice parameter, phase changes, amorphization, swelling, evolution of thermal and mechanical properties. Therefore, there are a lot of works to be done for the IMF materials, the material properties should meet requirements of ADS, and the process should be simple and low cost.

\section{Immobilization of HLW by ceramics}

The immobilization of highly radioactive waste 
materials in glass or ceramic hosts has been under investigation for many years. At the present time borosilicate glass is the generally accepted first generation waste form. As far back as the early 1950s, it was suggested that high level radioactive wastes could be immobilized in a polyphase ceramics. With the increasing demand for the immobilization of large quantities of HLW, there is a strong incentive to reconsider ceramic as waste forms. The use of ceramic materials depends upon the ability of the crystalline phases to accept a broad spectrum of chemical species within their lattices.

HLW contains a variety of MA and FPs, and different ceramics exhibit different ability for incorporation of radionuclides. A ceramic is required not only to contain as much nuclides as possible but also to possess sufficient leach resistance for a long period of time. Among the many potential advantages of ceramic waste forms, five are most notable: (1) low leach rates for many crystalline phases; (2) long-term resistance to radiation damage; (3) high waste loading; (4) excellent thermal and mechanical stability; and (5) simple processing and low cost. Table 1 summarizes some candidates of ceramics for waste forms [17]. The common structure of these materials include: spatial framework or channel are formed through the common edge or vertex of metal oxide polyhedron. In these structures, radionuclide cations can insert into the channel easily.
A single phase sodium zirconium phosphate (NZP) with the composition $\mathrm{NaZr}_{2}\left(\mathrm{PO}_{4}\right)_{3}$ has been the most widely studied ceramic waste form [18]. One advantage of NZP ceramic waste form is that it has a high waste loading. The NZP structure consists of a three-dimensional network of $\mathrm{PO}_{4}$ tetrahedra sharing corners with $\mathrm{ZrO}_{6}$ octahedra, with the interstitial space partly occupied by $\mathrm{Na}$ ions. It exhibits great compositional flexibility. Alkalis can substitute in the $\mathrm{Na}$ site. Divalent ions such as $\mathrm{Ca}, \mathrm{Ba}, \mathrm{Fe}, \mathrm{Mg}, \mathrm{Pb}$, and Sr substitute for two alkali ions [19]. Rare earth elements are assumed to enter the $\mathrm{Zr}$ site, with charge compensation being necessary for trivalent rare earth elements. Trivalent $\mathrm{Pu}$ substitutes for $\mathrm{Zr}$, forming either $\mathrm{Na}_{3} \mathrm{Pu}_{2}\left(\mathrm{PO}_{4}\right)_{3}$ or $\mathrm{Na}_{3} \mathrm{Pu}\left(\mathrm{PO}_{4}\right)_{2}$ depending on the $\mathrm{Pu}$-to- $\mathrm{PO}_{4}$ ratio [20]. Hexavalent molibdenum was taken to substitute directly on the $\mathrm{P}$ site, with appropriate charge compensation on other sites.

Waste loadings up to $20 \mathrm{wt} \%$ have been incorporated into this structure using sol-gel and sintering techniques while maintaining a single phase material. For loadings about $20 \%$ it has been observed that a two-phase material is formed, with monazite as the second phase. The leach studies of simulated waste forms based on NZP have shown reasonable resistance for the release of its constituents. The calculation of dissolution rates of NZP structure has demonstrated that it would take 20000 times longer to dissolve NZP than quartz [21]. Work has also been reported on

Table 1 Candidates of ceramics for waste forms

\begin{tabular}{lll}
\hline Composition type & Mineral name & Ideal formula \\
\hline Simple oxides & Zirconia & $\mathrm{ZrO}_{2}$ \\
\hline \multirow{4}{*}{ Complex oxides } & Pyrochlore & $(\mathrm{Na}, \mathrm{Ca}, \mathrm{U})_{2}\left(\mathrm{Nb}, \mathrm{Ti}, \mathrm{Ta}_{2} \mathrm{O}_{6}\right.$ \\
& Perovskite & $\mathrm{CaTiO}_{3}$ \\
& Zirconolite & $\mathrm{CaZrTi}_{2} \mathrm{O}_{7}$ \\
& Hollandite & $\mathrm{BaTi}_{8} \mathrm{O}_{16}$ \\
& Spinel & $\mathrm{MgAl}_{2} \mathrm{O}_{4}$ \\
\hline \multirow{5}{*}{ Silicates } & Zircon & $\mathrm{ZrSiO}_{4}$ \\
& Thorite & $\mathrm{ThSiO}_{4}$ \\
& Britholite & $\left(\mathrm{Ca}_{2} \mathrm{Ce}_{5}\left(\mathrm{SiO}_{4}\right)_{3}(\mathrm{OH}, \mathrm{F})\right.$ \\
& Titanite & $\mathrm{CaTiSiO}_{4} \mathrm{O}$ \\
\hline \multirow{3}{*}{ Phosphates } & Monazite & $\mathrm{LnPO}_{4}$ \\
& Xenotime & $\mathrm{YPO}_{4}$ \\
& NZP & $\mathrm{NaZr}_{2}\left(\mathrm{PO}_{4}\right)_{3}$ \\
& p-zirconium phosphate & $\mathrm{HZr}_{2}\left(\mathrm{PO}_{4}\right)_{3}$ \\
& Th-pyrophosphate & $\mathrm{Th}_{4}\left(\mathrm{PO}_{4}\right)_{4} \mathrm{P}_{2} \mathrm{O}_{7}$ \\
\hline
\end{tabular}


substitution of $\mathrm{Ti}$ for $\mathrm{Zr}$ to yield a sodium titanium phosphate (NTP), which under suitable conditions can accommodate up to $60 \%$ waste loadings [22].

$137 \mathrm{Cs}$ and $90 \mathrm{Sr}$ have relatively long half-life of approximately 30 years, they are typical high level radioactive wastes generated from spent nuclear fuels, if immobilized in ceramic forms the heat treatment temperature should be lower than $1000{ }^{\circ} \mathrm{C}$, in order to avoid the volatilization of $\mathrm{Cs}$ and $\mathrm{Sr}$. The chemical formula are $\mathrm{CsZr}_{2}\left(\mathrm{PO}_{4}\right)_{3}$ and $\left.\mathrm{SrZr}_{4}\left(\mathrm{PO}_{4}\right)_{6}\right]$ when zirconium phosphates used as the matrices in waste form, these three-dimensional structures can be formed by two methods. One method is the thermal treatment at $1000{ }^{\circ} \mathrm{C}$ of a gel formed from the aqueous solution of $\mathrm{CsNO}_{3}$ or $\mathrm{Sr}\left(\mathrm{NO}_{3}\right)_{2}, \mathrm{ZrO}\left(\mathrm{NO}_{3}\right)_{2}$ and $\mathrm{H}_{3} \mathrm{PO}_{4}$. The second method is ion exchange of $\mathrm{Cs}$ or $\mathrm{Sr}$ into $\mathrm{Zr}\left(\mathrm{HPO}_{4}\right)_{2} 2 \mathrm{H}_{2} \mathrm{O}$ in aqueous solution followed by thermal treatment at $850-1000{ }^{\circ} \mathrm{C}$. Result showed that when heated at $1000{ }^{\circ} \mathrm{C}$, impurity phases such as $\mathrm{ZrP}_{2} \mathrm{O}_{7}$ and $\mathrm{CsPO}_{3}$ or $\mathrm{Sr}\left(\mathrm{PO}_{3}\right)_{2}$ appeared and these phases led to the poor $\mathrm{Cs}$ and $\mathrm{Sr}$ leaching resistance [23].

Nakayama and Itoh [24,25] investigated the immobilization behaviors of radioactive $\mathrm{Cs}$ or $\mathrm{Sr}$ using the crystalline proton type zirconium phosphate $\left(\mathrm{HZr}_{2}\left(\mathrm{PO}_{4}\right)_{3}\right)$. The process is: An aqueous solution of $\mathrm{Cs}\left(\mathrm{NO}_{3}\right)_{2}$ or $\mathrm{Sr}\left(\mathrm{NO}_{3}\right)_{2}$ was added to $\mathrm{HZr}_{2}\left(\mathrm{PO}_{4}\right)_{3}$ powder and then completely mixed. The mixture was dried, prepared by thermal treatment in the temperature range of $650-1200{ }^{\circ} \mathrm{C}$ for $5 \mathrm{~h}$. They found that the Cs or $\mathrm{Sr}$ immobilized material is thermally and chemically resistant, and the excellent leaching resistance is attained at $700{ }^{\circ} \mathrm{C} . \mathrm{HZr}_{2}\left(\mathrm{PO}_{4}\right)_{3}$ is one of the promising ceramics for immobilizing $\mathrm{Cs}$ or $\mathrm{Sr}$.

The most well-known ceramic technology is Synroc (synthetic rock), which was developed by Ringwood and coworkers in Australia in the 1970s $[26,27]$. Synroc is a titanate-based ceramic containing several mineral phases such as hollandite and $\mathrm{BaAl}_{2} \mathrm{Ti}_{6} \mathrm{O}_{16}$, for sequestration of $\mathrm{Cs}, \mathrm{Ba}$ and $\mathrm{Rb}$; zirconolite, $\mathrm{CaZrTi}_{2} \mathrm{O}_{7}$, for sequestration of a variety of actinides, lanthanides and $\mathrm{Sr}$; perovskite $\mathrm{CaTiO}_{3}$ for $\mathrm{Sr}$, actinides and lanthanides; and non-stoichiometric titanium oxides $\mathrm{Ti}_{n} \mathrm{O}_{2 n-1}$. Although the production of Synroc is more complex than that of glass waste forms, it is generally accepted that the leach resistance of the Synroc matrix is superior to that of glass.

Figure 5 shows the three major processes for preparing Synroc waste forms, the radioactive waste

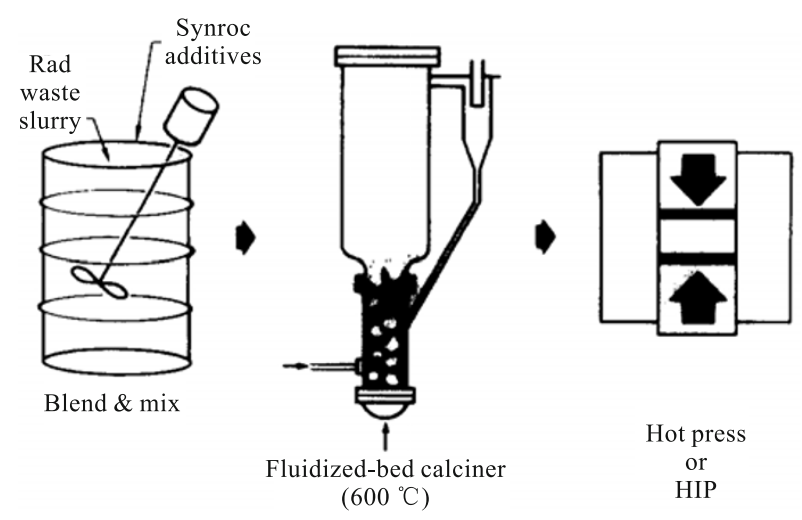

Fig. 5 Three major processes for preparing Synroc waste forms [3].

and Synroc additives are simply blended in a large tank, then fluidized bed calciner is used to dry the slurry, finally HIP or hot press is used to form monolithic solids [3]. Self-propagating high temperature synthesis (SHS) is a promising method to prepare Synroc waste forms [28].

Table 2 summarizes some properties of Synroc. Waste loadings of between $60-65 \mathrm{wt} \%$ have been achieved for Synroc waste forms. This corresponds to a volumetric concentration of $2.3-2.5 \mathrm{~g} / \mathrm{cm}^{3}$ and an equivalent Curie content of about $1.0 \mathrm{Ci} / \mathrm{cm}^{3}$. The leaching test is carried out according to the MCC-1 [29]. Distilled water $(\mathrm{pH}=5.80)$ with a temperature of $90{ }^{\circ} \mathrm{C}$ is used as leaching agent. Radionuclide concentrations are determined in the leaching solutions. The leaching rate of actinide $\alpha$ is given by: $R_{\alpha}=m_{\alpha} /\left(f_{\alpha} S t_{n}\right)\left[\mathrm{g} /\left(\mathrm{cm}^{2}\right.\right.$ day $\left.)\right]$, where $m_{\alpha}$ is the mass of actinide $\alpha$ in the solution, $f_{\alpha}$ is the mass composition of actinide $\alpha$ in the initial sample, $S$ is the open geometric surface of the sample, and $t_{n}$ is the leaching duration. The dissolution rate of Synroc matrix is at least 1000 times lower compared with a borosilicate glass. Unlike

Table 2 Properties of Synroc composites

\begin{tabular}{cc}
\hline Flexural strength $(\mathrm{MPa})$ & 65 \\
Compressive strength $(\mathrm{MPa})$ & 350 \\
Youngs modulus $(\mathrm{MPa})$ & $1.4 \times 10^{5}$ \\
Microhardness $\left(\mathrm{g} / \mathrm{mm}^{2}\right)$ & $>950$ \\
Density $\left(\mathrm{g} / \mathrm{cm}^{3}\right)$ & $4-6$ \\
Thermal conductivity $(\mathrm{W} / \mathrm{mK})$ & 2 \\
Thermal expension coeff $\left({ }^{\circ} \mathrm{C}\right)$ & $11 \times 10^{-6}$ \\
Leached rate $\left(\mathrm{g} /\left(\mathrm{m}^{2} \mathrm{~d}\right)\right)$ & $10^{-2}-10^{-3}$ \\
\hline
\end{tabular}


borosilicate glasses, the $\mathrm{pH}$ of the leachant has only a relatively small effect on the durability of Synroc [30]. The most durable phase in Synroc is zirconolite, followed by the spinel, hollandite, perovskite, and finally, the least durable crystalline phase, nepheline.

\subsection{Zirconolite}

Zirconolite is one of the key mineral components for many Synroc formulations, has long been recognized as a radiation resistant and chemically durable phase. It is suitable to host actinides. Zirconolite, as a derivative of the fluorite structure type, can be viewed as a condensed version of the pyrochlore structure, it consists of alternating layers of $(\mathrm{Ca}, \mathrm{Zr})$ polyhedra and $\mathrm{Ti}$ polyhedra. The main differences between the pyrochlore $\left(\mathrm{A}_{2} \mathrm{~B}_{2} \mathrm{X}_{6} \mathrm{Y}\right)$ and zirconolite structures are that pyrochlore contains three dimensional arrays of corner-linked B-X octahedra whereas zirconolite contains only two dimensional $\mathrm{Ti}-\mathrm{O}$ octahedra, and that $\mathrm{A}$ cations in pyrochlore are strongly bonded to only two anions, whilst in zirconolite $\mathrm{Ca}-, \mathrm{Zr}-$ and Ti-site cations are 8-, 7- and 6-fold coordinated, respectively. Figure 6 is the end-member of titanate-based zirconolite, $2 \mathrm{M}$ polytype $\mathrm{CaZrTi}_{2} \mathrm{O}_{7}$, in which $\mathrm{Ca}$ and $\mathrm{Zr}$ have 8- and 7-fold coordination, respectively, with no site symmetry elements other than the identity operator. Different polytypes (e.g., 3T, $3 \mathrm{O}, 4 \mathrm{M})$ arise through solid solutions towards lanthanide and actinide-bearing end-members Zirconolite.

The waste form mineral phase assemblage was designed to incorporate the radioisotopes via substitution for elements in the target mineral crystal lattices. For example: actinides (Ac) and rare earth (RE)

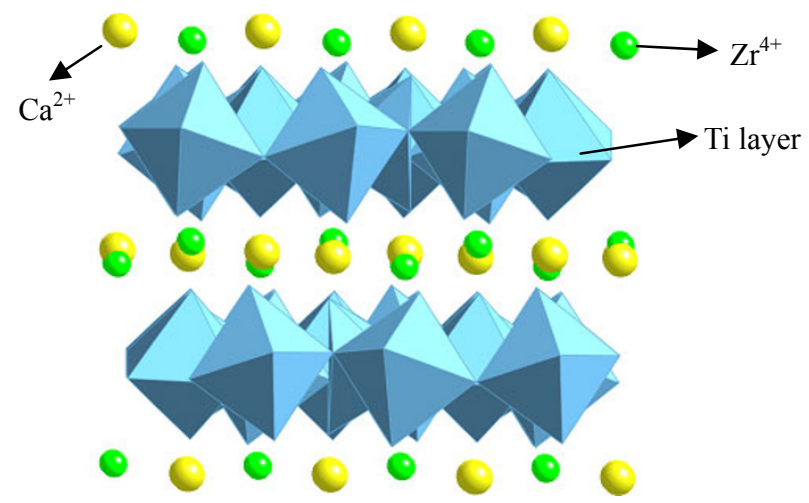

Fig. 6 Stereographic projection of the unit cell of 2M-monoclinal polytype zirconolite. In a monoclinal system, the unit cell is an oblique prism with a rhomboid base [31]. fission products were targeted to enter zirconolite $\left(\mathrm{CaZrTi}_{2} \mathrm{O}_{7}\right)$ via, e.g., $\mathrm{Pu}^{4+} \rightarrow \mathrm{Zr}^{4+}$ and $2(\mathrm{RE}, \mathrm{Ac})^{3+} \rightarrow$ $\mathrm{Ca}^{2+}+\mathrm{Zr}^{4+}$.

\subsection{Hollandite}

$\left(\mathrm{Ba}_{x}, \mathrm{Cs}_{y}\right)(\mathrm{M}, \mathrm{Ti})_{8} \mathrm{O}_{16}$ hollandite ceramics, with $x+y<2$ and $\mathrm{M}=$ divalent or trivalent cation appeared as the best candidates for immobilization of radioactive cesium, because of the occurrence of $\mathrm{Ti}^{4+}$ ions in the structure that can act as electron traps during $\beta$-decay $\left(\mathrm{Ti}^{4+}+\mathrm{e}^{-}\left(\beta^{-}\right) \rightarrow \mathrm{Ti}^{3+}\right)$. Moreover, hollandite was also shown to be able to incorporate $\mathrm{Rb}^{+}$and $\mathrm{Sr}^{2+}$ ions in its structure.

It was very difficult to incorporate significant amounts of $\mathrm{Cs}$ in $\mathrm{BaAl}_{2} \mathrm{Ti}_{6} \mathrm{O}_{16}$ without partially reducing $\mathrm{Ti}^{4+}$ to $\mathrm{Ti}^{3+}$, because of the small size of $\mathrm{Al}^{3+}$ (ionic radius $0.535 \AA$ ). The ionic radius of $\mathrm{Ti}^{4+}$ and $\mathrm{Ti}^{3+}$ is $0.605 \AA$ and $0.670 \AA$, respectively. $\mathrm{As} \mathrm{Fe}^{3+}$ has ionic radius $(0.645 \AA)$ larger than $\mathrm{Al}^{3+}$ ionic, the occurrence of $\mathrm{Fe}^{3+}$ in site $\mathrm{B}$ of $\mathrm{Ba}(\mathrm{AlFe})_{2} \mathrm{Ti}_{6} \mathrm{O}_{16}$ hollandite facilitated $\mathrm{Cs}$ incorporation in tunnels [32]. Figure 7 is the $\left(\mathrm{Ba}_{\mathrm{x}}, \mathrm{Cs}_{\mathrm{y}}\right)(\mathrm{M}, \mathrm{Ti})_{8} \mathrm{O}_{16}$ hollandite structure, $\mathrm{c}$-axis is directed along the tunnels which corresponds to the tetragonal structure. $\mathrm{Ba}, \mathrm{Cs}$ cations are incorporated in tunnels in the framework of $(\mathrm{M}, \mathrm{Ti}) \mathrm{O}_{6}$ octahedra. It can be seen from Fig. 7 that large cations in site B enlarged the tunnel cavities which makes Cs come into the structure easily.

\subsection{Multi-barrier waste forms}

Multi-barrier waste forms consist of a series of glass or ceramic barriers, just like coated particles for high temperature gas cooled reactor. Waste contained phases are either encapsulated in other more durable phases or the particles are coated with another phase. The coatings are applied to enhance chemical durability, mechanical strength or the thermal stability of the material. The coatings may be conventional ceramics (e.g., $\mathrm{Al}_{2} \mathrm{O}_{3}, \mathrm{TiO}_{2}$, or $\mathrm{SiO}_{2}$ ), carbon products (e.g., $\mathrm{PyC}, \mathrm{SiC}$ ) and glass. The advantages of these forms are increased chemical durability, and in the case of metal encapsulation, higher thermal conductivity.

\subsection{Selection criteria}

The selection of a waste form depends on three rather independent criteria.

(1) The composition of the waste stream. The 
(a)

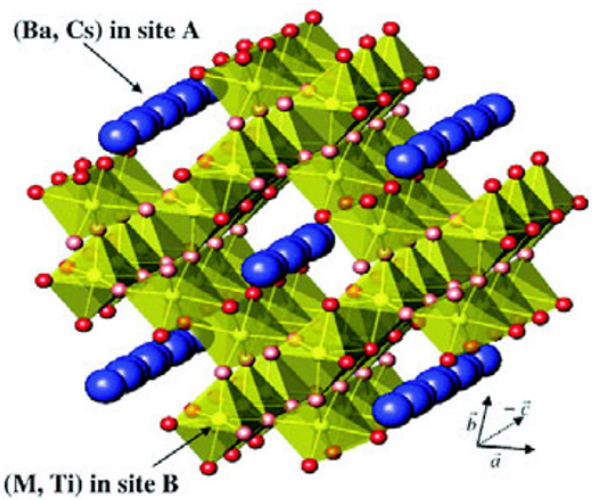

(b)

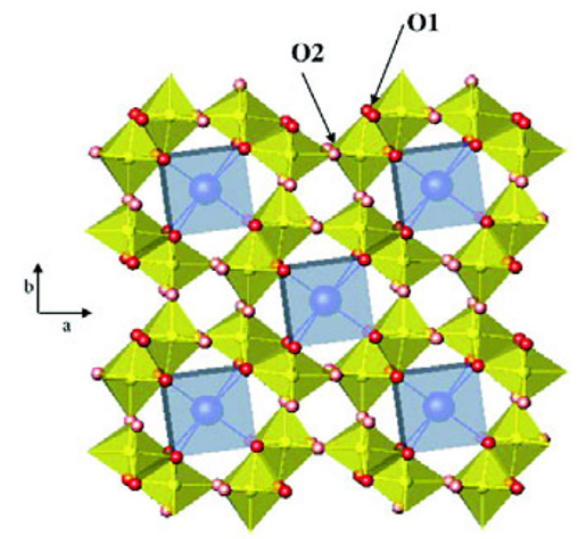

Fig. 7 Structure of $\left(\mathrm{Ba}_{x}, \mathrm{Cs}_{y}\right)(\mathrm{M}, \mathrm{Ti})_{8} \mathrm{O}_{16}$ hollandite.

(a) Perspective view, (b) Projection along the $c$-axis $\mathrm{M}$ : trivalent or divalent cation, $\mathrm{O} 1$ and $\mathrm{O} 2$ are two kinds of oxygen sites [32].

composition of actinides and fission products in HLW are complex, the waste form needs to incorporate a wide variety of elements with very different chemical properties. For example, many HLW contains appreciable amounts of sodium, sodium tends to form soluble Na-bearing minor phases and to reduce the durability of Synroc. It was concluded that the chemical durability of Synroc could not be maintained when the $\mathrm{Na}_{2} \mathrm{O}$ content in Synroc exceeded $2 \mathrm{wt} \%$. To improve the durability of Synroc, one approach is to add rare earth element, another is the inclusion of freudenbergite as an additional phase for immobilizing sodium [33].

(2) The properties of the waste form. Most important properties of the waste form are: (i) loading ability; (ii) the chemical durability and long-term stability; (iii) the response to radiation damage, particularly from the alpha-decay events. In addition to experimental studies, it is also very useful to model the irradiation behavior; (iv) simple and reliable synthesis processes that can be managed remotely with minimum exposure to workers.
(3) The properties of the geologic repository. For each type of repository, the geochemical and hydrological conditions determine the environment of the waste form. Temperature, redox conditions and the amount and rate of flow of water can have important effects on the waste form.

At the present time, borosilicate glass is the generally accepted as the first generation waste form, many commercial vitrification plants are now in operation throughout the world using borosilicate glass as the host for the immobilization of HLW. As the advanced fuel cycle technology developed, many different types of ceramic materials have been investigated as possible candidate hosts for actinide phases, these include, in particular, titanate, zirconate and phosphate based ceramics, together with iron phosphate based ceramics. Each host material has its own merits and limitations, much work is therefore needed to design new materials and to research the behavior of waste forms with active materials.

\section{Summary}

After several decades of research on crystalline ceramics for the immobilization of HLW, there are now a variety of structures and compositions that are quite desirable for the long-term disposal of HLW. With the exception of Synroc, the majority of alternative waste forms have only been studied on a small, non-radioactive scale. Further researches need to be developed to evaluate the performances of existed ceramics, such as polytype, zirconolite and hollandite, especially irradiation performance, and to find ideal process of simple and reliable synthesis technique.

Composite ceramics will be more common than single phase assemblages just because of the complexity of the liquid waste composition. Even when the ceramic consists of a dominant single phase, other phases (crystalline and glass) segregated along grain boundaries is beneficial to host impure nuclides. Effect of grain size and polyphase boundary on the leach ability and mechanical properties need to be investigated. New materials or composites with specific waste-loadings, chemically durable and radiation resistant should be designed and manufactured. These new waste forms will find many applications in advanced fuel cycles for the storage and disposal of radionuclides or as inert matrix fuels for 
accelerators. The future of HLW forms is bright and still under active development.

\section{References}

[1] Sengupta P. A review on immobilization of phosphate containing high level nuclear wastes within glass matrix: Present status and future challenges. J Hazardous Mater 2012, 235-236: 17-28.

[2] Abu-Khader MM. Recent advances in nuclear power: A review. Prog Nucl Eng 2009, 51: 225-235.

[3] Hench LL, Clark DE, Campbell J. High level waste immobilization forms. Nucl Chem Waste Manag 1984, 5: 149-173.

[4] Luo SG, Yang JW, Zhu XZ. Synroc solidification of actinide wastes. Acta Chimica Sinica 2000, 58: 1608-1614.

[5] Deokattey S, Bhaskar N, Kalyane VL, et al. Borosilicate glass and Synroc R\&D for radioactive waste immobilization: An international perspective. JOM-J Minerals Metals Mater Soc 2003, 55: 48-51.

[6] Gu ZM. Nuclear Waste Disposal Technique. Beijing: Atomic Energy Press, 2009: 359-368.

[7] Babelot JF, Conrad R, Gruppelaar H, et al. Development of fuels for the transmutation in the frame of the EFTTRA European collaboration. Int. Conf. on Future Nuclear Systems (Global'97). Yokohama, 1997, 1: 676-679.

[8] Degueldre C, Paratte JM. Concepts for an inert matrix fuel: An overview. J Nucl Mater 1999, 274: $1-6$.

[9] International Atomic Energy Agency. Viability of inert matrix fuel in reducing plutonium amounts in reactors. IAEA-TECDOC-1516, 2006.

[10] Chauvin N, Konings RJM, Matzke H. Optimization of inert matrix fuel concepts for americium transmutation. J Nucl Mater 1999, 274: 105-111.

[11] Fernandez A, Konings RJM, Somers J. Design and fabrication of specific ceramic-metallic fuels and targets. J Nucl Mater 2003, 319: 44-50.

[12] Delage F, Belin R, Chen XN, et al. ADS fuel developments in Europe: Results from the EUROTRANS integrated project. Eng Procedia 2011, 7: 303-313.

[13] Information on http://www.ne.doe.gov/pdfFiles/afciFy2005StatusRp tToCongress.pdf.

[14] Fernandez A, Haas D, Hiernaut JP, et al. Overview of ITU work on inert matrix fuels. In 9th IEMP. 2006.

[15] Boidron M, Chauvin N, Garnier JC, et al.
Transmutation studies in France, R\&D programme on fuels and targets. In Proc. Conf. on Partitioning and Transmutation. Madrid, 2000.

[16] Pounchon MA, Ledergerber G, Ingold F, et al. Sphere-pac and VIPAC fuel. Ch 3.11. Compreh Nucl Mater 2012, 3: 275-312.

[17] Ewing RC. Ceramic matrices for plutonium disposition. Prog in Nucl Energy 2007, 49: 635-643.

[18] Boatner LA, Sales BC. Monazite. In Radioactive Waste Forms for the Future. Lutze W, Ewing RC, Eds. North-Holland, Amsterdam, 1988: 495-564.

[19] Roy R, Yang LJ, Alamo J, et al. Single phase NZP ceramic radioactive waste form. In Scientific Basis for Nuclear Waste Management VI. Brookins DG, Ed. North-Holland, Amsterdam, 1983: 15-21.

[20] Burnaeva AA, Volkov YF, Krjukova AI. Crystal-chemical features of sodium-Pu(III) double phosphates and certain other f-element phosphates. Radiokhimiya 1994, 36: 289-294.

[21] Scheetz BE, Agrawal DK, Breval E, et al. Sodium zirconium phosphate (NZP) as a host structure for nuclear waste immobilization: A review. Waste Manag 1994, 14: 489-505.

[22] Yang LJ, Komarneni S, Roy R. Titanium-phosphate (NZP) waste form. Nucl. Chem. Waste Management, Vol. 8. In Advances in Ceramic. Wicks GG, Ross WA Eds. The Am. Ceram. Soc., 1984: 255-262.

[23] Ishida M, Kikuchi K, Yanagi T, et al. Leaching behavior of crystalline phosphate waste forms. Nucl Chem Waste Manag 1986, 6: 127-131.

[24] Itoh K, Nakayama S. Immobilization of cesium by crystalline zirconium phosphate. J Mater Sci 2002, 37: 1701-1704.

[25] Nakayama S, Itoh K. Immobilization of strontium by crystalline zirconium phosphate. $J$ Euro Ceram Soc 2003, 23: 1047-1052.

[26] Ringwood AE, Kesson SE, Ware NG. Immobilization of U.S. defense waste using Synroc process. In Scientific Basis for Nuclear Waste Management. New York: Plenum Press, 1980: 265.

[27] Ringwood AE, Kesson SE, Ware NG, et al. Immobilization of high level nuclear reactor wastes in Synroc. Nature 1979, 278: 219-223.

[28] Vinokurov SE, Kulyako YM. Immobilization of actinides in pyrochlore-type matrices produced by self-propagating high-temperature synthesis. $C R$ Chimie 2007, 10: 1128-1130.

[29] US DOE. Nuclear waste materials handbook (test methods). Rep. DOE/TIC-11400, Washington, DC: Technical Information Center, 1981.

[30] Ringwood AE, Kesson SE, Reeve KD, et al. Synroc. In Radioactive Waste Forms for the Future. Lutze W, 
Ewing RC, Eds. Amersterdam: Elsevier, 1988: 233-334.

[31] Perera DS, Begg BD, Vance ER. Application of crystal chemistry in the development of radioactive wasteforms. The AZo Journal of Materials 2005, DOI: 10.2240/azojomo 0132.

[32] Aubin-Chevaldonnet V, Caurant D, Dannoux A, et al. Preparation and characterization of
$(\mathrm{Ba}, \mathrm{Cs})(\mathrm{M}, \mathrm{Ti})_{8} \mathrm{O}_{16}\left(\mathrm{M}=\mathrm{Al}^{3+}, \mathrm{Fe}^{3+}, \mathrm{Ga}^{3+}, \mathrm{Cr}^{3+}, \mathrm{Sc}^{3+}\right.$, $\mathrm{Mg}^{2+}$ ) hollandite ceramics developed for radioactive cesium immobilization. J Nucl Mater 2007, 366: 137-160.

[33] Luo SG, Li L, Tang B, et al. Synroc immobilization of high level waste (HLW) bearing a high content of sodium. Waste Manag 1998, 18: 55-59. 